\title{
単ドット式ペーパーディスク型 地下水流向流速計の開発 DIVELOPMENT OF THE SINGLE DOT TYPE PAPER DISK GRONDWATER VELOCIMETER
}

\author{
山本浩一 1 - 小野文也 2 - 神野有生 3 - 関根雅彦 4 \\ Koichi YAMAMOTO, Fumiya ONO, Ariyo KANNO and Masahiko SEKINE \\ 1正会員 山口大学准教授 大学院理工学研究科( ₹755-8611山口県宇部市常盤台2-16-1) \\ 2学生会員 山口大学大学院理工学研究科 (下755-8611山口県宇部市常盤台2-16-1) \\ 3 正会員 山口大学助教 大学院理工学研究科( ₹755-8611山口県宇部市常盤台2-16-1) \\ 4正会員 山口大学教授 大学院理工学研究科( ₹755-8611山口県宇部市常盤台2-16-1)
}

\begin{abstract}
Various groundwater velocimeters were developed to measure groundwater flow. However, those conventional velocimeters need electricity as well as high cost. Our objective was to develop the low cost and unplugged groundwater velocimeter. In this study, single dot type paper disk groundwater velocimeter was tested. Calibration of the velocimeter was done with calibrating sand vessel. As a result of the study, with 5 minutes measurement, velocity range of $0.3 \mathrm{~cm} / \mathrm{min}-1.5 \mathrm{~cm} / \mathrm{min}$ could be measured. With 60 minutes measurement, velocity range of $0.03 \mathrm{~cm} / \mathrm{min}-0.1 \mathrm{~cm} / \mathrm{min}$ could be measured. From the result of the field observation, flow direction of the calorimetry method matched our method for sufficient length of the dot tailing on the paper disc.
\end{abstract}

Key Words: Groundwater, velocimeter, paper disk, Sarobetsu mire

\section{1. はじめに}

近年，有害物質の不法投棄や，地下水・土䁃污染が顕 在化している. 地下水・土壌污染が発生した際, 污染源 を特定するために地下水の流向および流速を測定する必 要がある. 地下水の流向・流速計測方法のうち一つの観 測井で観測を行う方法（単孔式）には画像解析法 ${ }^{1}$, 熱 量法2，超音波反射エコーを利用した計測方法3)などがあ る.トレーサーを利用する多孔式と異なり，1つの観測 井で地下水の流向・流速測定が可能である. しかしなが らすべての流速計は現地測定の際電源が必要であり，か つ装置が高価である. したがって多数の井戸で一斉に観 測することは難しく, 多数の井戸を観測するためにはそ れだけ長い時間を要することになる. 安価で手軽に使用 可能な地下水流向・流速計があれば，複数台の観測機材 を用いて広範囲の井戸を一斉に観測することができる. このような背景のもと, 著者らは安価で電源を必要とし ないペーパーディスク型地下水流向流速計の開発を行っ
ている45). 本装置の基礎原理は紙上に印刷されたドット から溶出した染料インクが透水体内を移動する水によっ て輸送されることを利用したものである．実際には画用 紙に印刷したインクの軌跡（テーリング）を画像解析し て地下水流向流速を求める.

従来のペーパーディスク型地下水流向・流速計にはそ の形状の設計に伴う根本的な問題点があった．測定の際 には複数のドットを円環状のペーパーディスクに印刷したも のを用いていた ${ }^{45)}$ )が, 装置の中心には支持体(不透水部) があるため, センサー内を浸透する水の流線に及ぼす影響 が大きく, 流線が大きく曲がる. また, 透水部に空気が溜 まってしまいドットが濡れずに測定が不可能になることがた びたびあった(図-1).

そこで, スポンジの中心部から構造体を除き, 円柱状の透 水体をかで型の構造体で支える形式に変更した. さらに ペーパーディスクの中心にドットを1つだけ配置した新型の 装置を開発した. 本研究では室内実験水槽で装置の検定を 行い, 現地適用試験を行った. 


\section{2. 研究方法}

\section{（1）流速計センサー}

本装置はVP65パイプ (内径67mm) 用に作成した. セン サーの上下はアクリル円筒を配置し, 観測井のストレーナと 接する中央部に透水性スポンジ(メラシンスポンジ)を使用し， 透水体の保持装置として $2 \mathrm{~mm}$ 厚の $\mathrm{ABS}$ 樹脂の柱 ( $4 \mathrm{~mm}$ 幅) を装置の外周の片側に7つ設置し, 装置断面に空気抜き用 の穴を設けた(図-2).

スポンジは円筒形とし, 柱と接触する部分については溝 を切った. その他, 材質はアクリル樹脂とABS樹脂で構成し た. 観測井挿入後にスポンジ内部に残った空気を除去する 手段ししてスポンジの圧縮装置を加えた. 本装置をストレー ナ部分に静置後, スポンジを上から $2 \mathrm{~cm}$ 程度圧縮すること によって内部の空気を強制的に排出させることが可能であ る. また, ペーパーの回転を防ぐために柱で固定するため の爪を設けた.ペーパーディスク型地下水流向流速計 (PDV)の測定手順を図-3に示す. 測定手順は以下のようで ある. (1)まず二つのスポンジの間にディスクを挟む. (2)方位 を確かめ, ストレーナにスポンジが当たるまでゆっくり本体を 挿入する. 挿入後本体上部のノブを上下させてスポンジを 圧縮し, 空気を追い出す. (3)所定の時間静置する. (4)本体 をゆっくり引き上げてスポンジとペーパーディスクを取り出 す. (5)ペーパーディスクをスキャンして電子化する.

流速計の直径を変化させることでVP65以外にもVP50 にも適用できる。ただしその場合は流速計測範囲が VP65に比べて狭くなる.

\section{(2) ペーパーディスク}

図-4に単ドット式ペーパーディスクを示寸. 12角形の画用 紙(マルマン社製, $126.5 \mathrm{~g} / \mathrm{m}^{2}$ ) の中心に直径 $3 \mathrm{~mm}$ のドットを 配置した. 印刷はCanon Pixus 950iを用いて行った. インクは 黒色インク (Canon BCI-6BK)を用いた. 6色すべてのインク ホルダーに黒色インクを設置し, 当該インク以外の混入を避 けた。

\section{（3）画像解析方法}

\section{a) 画像取得方法}

測定後のペーパーディスクを乾燥後. フラッドベットスキヤ ナ(EPSON製 GT-7000U)を用いて電子化した. 電子化する 際の取得条件は600dpi, 露光-1, 八イライト255, シャド ウ60とした. 露光, ハイライト, シャドウはソフト固有のパラ メータであり, 画像の階調や明るさを制御するが, 電子化の 際にそれらは固定条件とした. ガンマ值は1と寸ることで画 像の階調を直線とした.

\section{b) 画像処理方法}

電子化した画像をオープンソースの画像解析ソフト Image-Jを用いて測定前のドットと測定後のテーリングごとに
RGBカラーモデルを用いて2值化処理を行った(図-6).

取得した画像はRGB分解してG(Green)の225以下の輝 度をテーリング，90以下の輝度を初期ドットとして解析した。 閾値の選定にあたってはR,G,Bそれぞれの閾值を変化させ て検量線を作成して最も決定係数が高かったものを採用し た. 計測時間によってはテーリング全体が薄くなり, 一定の 間值では初期ドットが抽出できないことがあったが，その際 には閾值を変化させて実験前のドットの面積と近くなるよう な閾值を採用して画像から初期ドットを抽出した. 初期ドッ卜 の重心位置はテーリングの重心移動距離および方位を求め るための基点として用いた.

二值化した画像について, 初期ドットは重心位置と面積, 真円度を取得し, テーリングは面積, 重心位置, テーリング のフェレ径, 楕円体近似した際の長径を取得した.

\section{c）流向算出方法}

初期ドットの重心の座標を $g(x, y)$ を起点とし, テーリング の重心の座標を $g^{\prime}\left(x^{\prime}, y^{\prime}\right)$ を終点とするべクトル $\boldsymbol{G}$ の方位 $\theta$ を 流向として定義した(図-4). $g(x, y)$ は直径3 mmの円の面 積に最も近く, 且つ真円度が1に近いドットを抽出したときの 重心の座標とした。

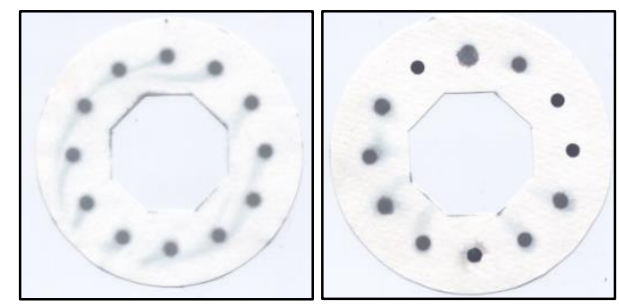

図-1リング型ペーパーディスクのテーリング(左 : 流線の 屈曲，右 : ドットの不十分な濡れ)

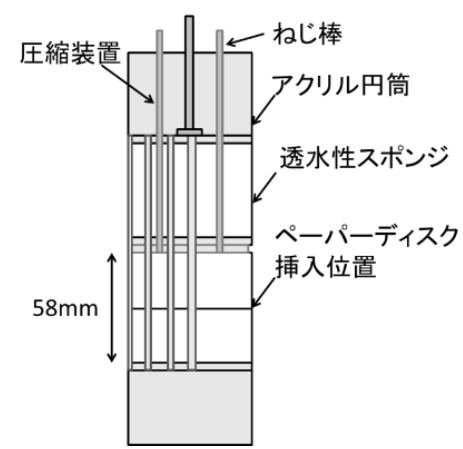

図-2 装置側面図（外径65 mm）

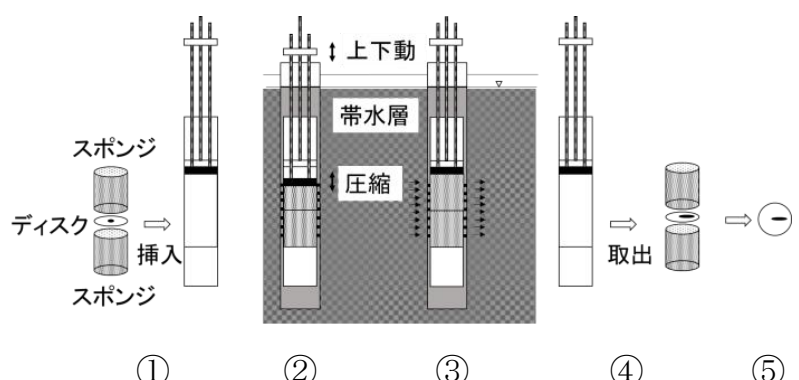

図-3 PDVの測定手順, (1) (5)は本文中に記載 


\section{d）流速算出方法}

流速の増大とともにテーリング長が増大寸る，そこで テーリング長に関する3種の指標と流速を比較した．指 標は重心移動に基づくテーリング長であるべクトル $\boldsymbol{G}$ の 大きさ，テーリングに外接する長方形の長辺(フェレ径), テーリングの近似楕円体の長径の三つを用いた。 これら の算出に当たってはImage-Jの粒子解析機能を利用した。

\section{（4）流向 ・流速の検定方法}

ダルシー流速とテーリングの関係から検定曲線を作成す るために室内実験を行った. 室内実験に用いた実験水槽 （図-5）の諸元を表-1に示す. 実験水槽は五号珪砂で満た し, ポンプで水を循環し水頭差を発生させた. ストレーナは 底面から $37 \mathrm{~cm}$ の間について $8 \mathrm{~mm} の$ 円孔を鳥格子で配 置したもので, 開口率は29.9\%である. 孔の密度は0.59個 / $\mathrm{cm}^{2}$ である.

流速はペリスタルテイックポンプ(Iuchi製 CTP-100)を用い て水槽内の水を循環させ発生させた. ダルシー流速はポン プ流量を断面積で除して算出した.

設定流向の方位は $0^{\circ}$ ，流速は測定時間5分の条件では $1.5,1.3,1.1,0.9,0.7,0.5,0.3,0.1 \mathrm{~cm} / \mathrm{min}$ の 8 パターン各流速 で3回測定した. また, 測定時間60分の条件ではより低流速 の実験を行うため, $0.09,0.07,0.05,0.03,0.01 \mathrm{~cm} / \mathrm{min} の 5$ パ ターンに変化させ, 各流速で4回測定した。計測時間の選 定に当たっては, 既存の熱量式流速計の計測範囲である $0.01 \mathrm{~cm} / \mathrm{min} \sim 1.0 \mathrm{~cm} / \mathrm{min}$ 目標しし，これを実現するような計 測時間を選んだ.

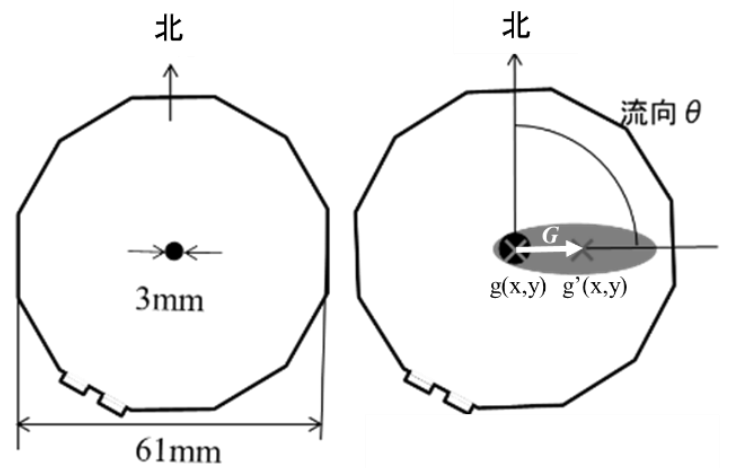

図-4＼cjkstart単ドット式ペーパーディスク

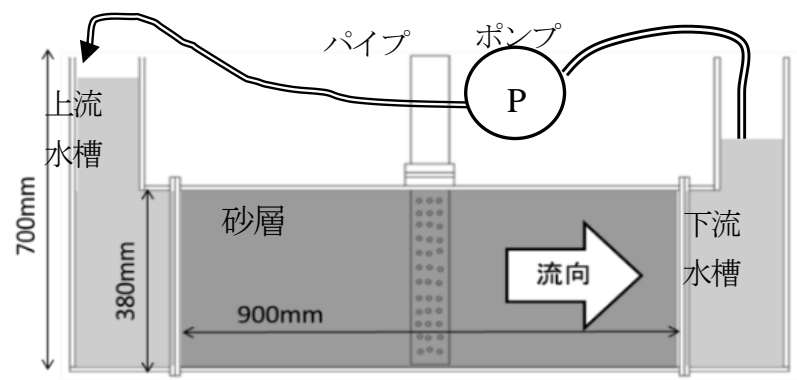

図-5 検定水槽

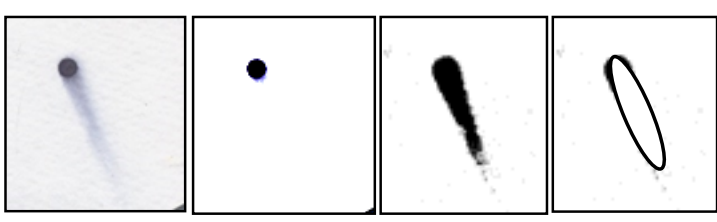

図-6テーリングの画像処理過程 （左）：8ビット画像 （中 左）：初期ドット抽出後 (中右）：テーリング抽出後 （右）：楕円体近似例

表-1＼cjkstart室内実験水槽の諸元

\begin{tabular}{cc}
\hline 項目 & 数值 \\
\hline 砂充填部 $(\mathrm{mm})$ & $\mathrm{B} 380 \times \mathrm{H} 380 \times \mathrm{L} 900$ \\
ハイプ内径 $(\mathrm{mm})$ & 67 \\
ストレーナ形状 & $8 \mathrm{~mm}$ 円孔 \\
ストレーナ開口率 & $29.9 \%$ \\
砂の種類 & 珪砂 5 号 \\
透水係数 & $0.13 \mathrm{~cm} / \mathrm{s}$ \\
ストレーナ区間 & $37 \mathrm{~cm}$ \\
\hline
\end{tabular}

表-2＼cjkstart各流速計による観測時間帯（2015. 7. 18-7. 19，サロベッ 湿原環境省特別実験区)

\begin{tabular}{|c|c|c|c|c|}
\hline No. & 観測井 & 装置 & & 日付·時刻 \\
\hline \multirow[t]{2}{*}{1} & W0.5 & 熱量式 & $7 / 18$ & $10: 00-12: 00$ \\
\hline & & PDV & $7 / 18$ & $15: 08-16: 08$ \\
\hline \multirow[t]{2}{*}{2} & & 熱量式 & $7 / 19$ & $02: 00-04: 00$ \\
\hline & & PDV & $7 / 19$ & 08:50-09:50 \\
\hline \multirow[t]{2}{*}{3} & & 熱量式 & $7 / 19$ & $16: 30-17: 30$ \\
\hline & & PDV & $7 / 19$ & $13: 18-14: 18$ \\
\hline \multirow[t]{2}{*}{4} & W1.0 & 熱量式 & $7 / 19$ & 11:41 -13:41 \\
\hline & & PDV & $7 / 19$ & $16: 32-17: 32$ \\
\hline
\end{tabular}

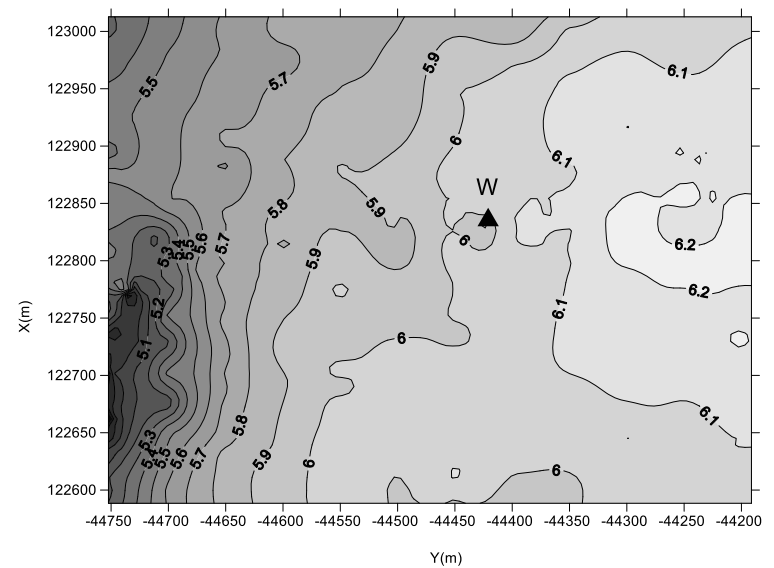

図-7 現地実験対象地の地形（サロベツ湿原環境省特別実験 区，単位: $m$ ，平面直角座標系第12系)

\section{（5）現地実験方法}

北海道天塩郡サロベツ湿原の環境省特別実験区のW地点 において熱量式地下水流向流速計とPDVの比較実験を 行った. 熱量式地下水流向流速計はアレック電子GFD-3 を用いた. 公称流速計測範囲 $0.01 \mathrm{~cm} / \mathrm{min} \sim 1 \mathrm{~cm} / \mathrm{min}$, 流速

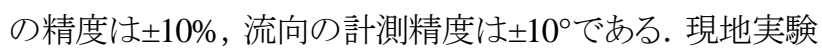


はW0.5観測井とW1.0観測井の2箇所で行った. 現地の地形 を図-7に示す．観測井はVP65塩ビパイプ(内径67mm)であ

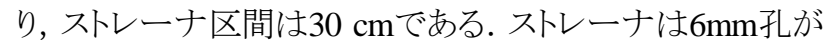
$30 \mathrm{~cm}$ の区間に合計192個であり，開口率は7.5\%である. ス卜 レーナ上部の地表面からの深度はそれぞれ $76 \mathrm{~cm}, 121 \mathrm{~cm}$ である. 透水係数はW0.5,W1.0それぞれ9.3 × $10^{-6} \mathrm{~m} / \mathrm{s}$, $0.15 \times 10^{-6} \mathrm{~m} / \mathrm{s}$ である. PDVによる観測時間は60分とした. 熱量式流速計の測定時間も60分であるが, センサーの温度 計の安定のため, 測定開始一時間前にセンサーを観測井 に挿入した. 現地実験は熱量式による測定とPDVによる測 定を可能な限り交互に行うようにした. 実験回数は合計4回 である. 実験した時間帯について表-2に示した.

\section{3. 研究結果および考察}

\section{（1）流速と流向の測定結果（5分間測定）}

図-8にダルシー流速と重心移動距離, 近似楕円体長径, フェレ径の関係を示した. 流速とこれらのパラメータの関係 に用いたデータは外れ值を除外している. 外れ值は測定值 を $x$, 平均值を $\mu$, 標準偏差を $\sigma$ としたとき, $|x-\mu|>\sigma$ となるものと した.

5 分間計測の3つの近似直線はどれも決定係数が 0.8 以上 となった. これらのうち最も決定係数が高かったのはテーリ ングのフェレ径であった.

次に流向の標準偏差と標準誤差(設定方位からの誤差)で あるが, 図-9から, 流速 $0.3 \mathrm{~cm} / \mathrm{min}$ 以下では流向の標準偏 差, 標準誤差が $20^{\circ}$ を超えることがわかる. また, 流速 1.5 $\mathrm{cm} / \mathrm{min}$ 以上ではテーリングが紙面からはみ出して解析不可 能になる可能性がある. 本装置では16方位 $\left(22.5^{\circ}\right)$ の精度 を目指しており, 5分間の測定では $0.3 \mathrm{~cm} / \mathrm{min} ~ 1.5 \mathrm{~cm} / \mathrm{min}$ の 地下水流向・流速を計測可能であるとみられた。 図-10に流 速の推定結果を示す. 流速の二乗平均誤差は重心移動法, 楕円体近似, フェレ径それぞれ $0.33 \mathrm{~cm} / \mathrm{min}, 0.31 \mathrm{~cm} / \mathrm{min}$, $0.30 \mathrm{~cm} / \mathrm{min}$ となった.

\section{（2）流速と流向の測定結果（60分間計測）}

図-11に60分間計測におけるダルシー流速と重心移動距 離, 近似楕円体長径, フェレ径の関係を示した. 5分間測定 の時と同様に流速とこれらのパラメータの関係に用いた データは同じ基準で外れ值を除外している.

60分間計測の近似直線の決定係数は0.65以上であった が, 最も決定係数が高かったのは重心移動距離を用いるも のであった. 流速が低い条件では拡散によりドットの後方に も広がるテーリングが発生することで, 時間に応じて流速と 無関係にテーリングの幅が増大する. 重心の移動を解析す る方法ではこの効果がキャンセルされるため，60分間の計 測では重心の移動が最も決定係数が高かったと考えられる. 60 分間で計測できる上限については，フェレ径が 0.1 $\mathrm{cm} / \mathrm{min}$ に達すると数值が伸びておらず, 測定は $0.1 \mathrm{~cm} / \mathrm{min}$ 以下が上限とみられる.
図-12から0.03 cm/min以上では標準偏差および標準誤 差は $20^{\circ}$ 以内に収まり, 良好な流向測定精度が得られて いる. したがって 60 分の観測時間では $0.03 \mathrm{~cm} / \mathrm{min} \sim 0.1$ $\mathrm{cm} / \mathrm{min}$ の流向・流速計測に用いることができると考えら れた.これはテーリングのフェレ径に換算すると $1.3 \mathrm{~cm}$ $\sim 2.6 \mathrm{~cm}$ になる. 現地での具体的な計測方法としては5分, 10分, 20分, 30分, 60分の計測時間における検量線を作 成しておくことを前提として，上記の観測時間で計測を 順次行って，テーリングが上記の範囲に入った計測時間 における検量線を用いることで流向・流速を求めること ができる. 図-13に流速の推定結果を示す. 流速の二乗平 均誤差は重心移動法, 楕円体近似, フェレ径それぞれ0.025 $\mathrm{cm} / \mathrm{min}, 0.031 \mathrm{~cm} / \mathrm{min}, 0.029 \mathrm{~cm} / \mathrm{min}$ となった.

流向の標準偏差と標準誤差(設定方位からの誤差)では

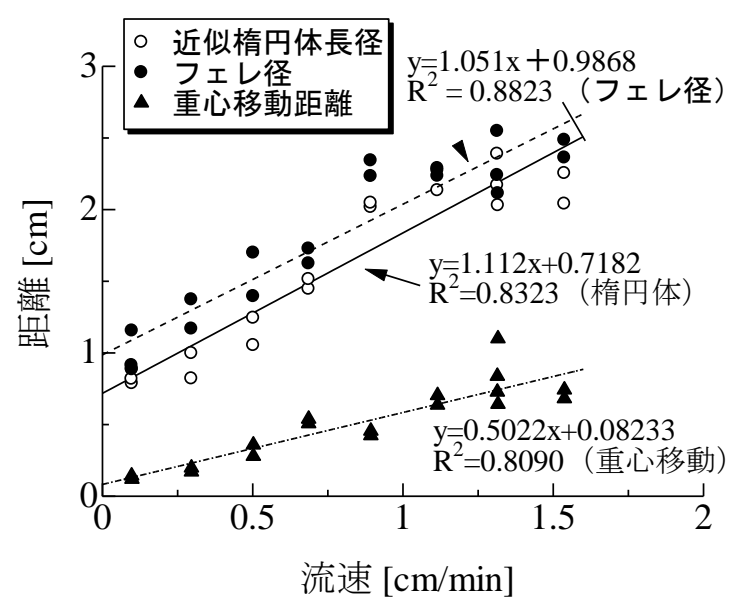

図-8５分計測時におけるテーリングの重心移動距離，楕円体 近似長径, フェレ径とダルシ一流速の関係

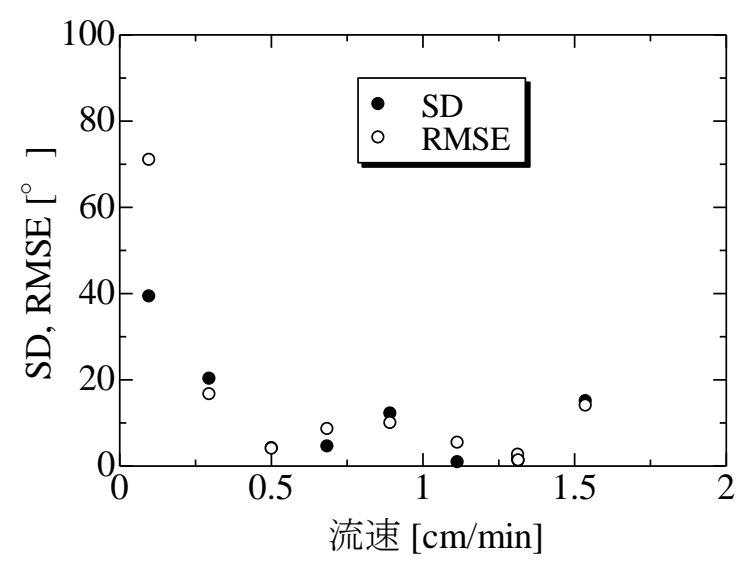

図-9５分計測時における流向の標準偏差（SD）および二乗 平均誤差 (RMSE) 


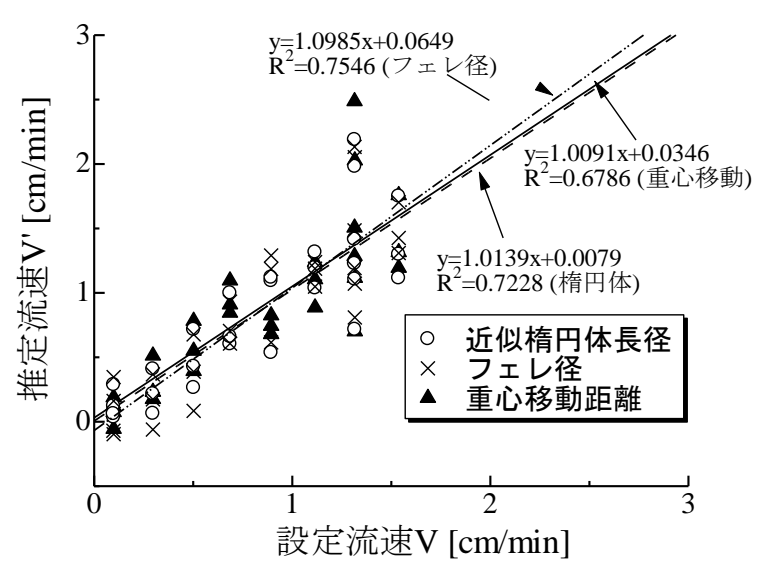

図-10 5分計測時における重心移動距離, 楕円体近似長径, フェレ径を用いたダルシ一流速の推定結果

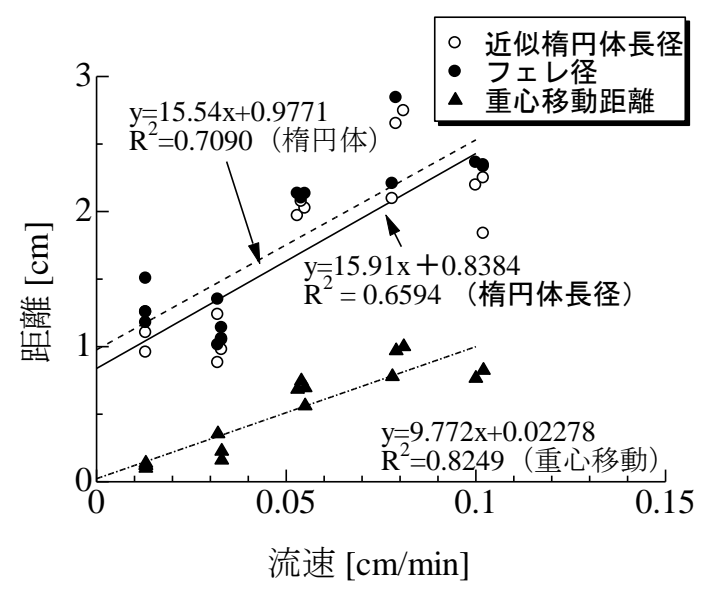

図-11 60分計測時におけるテーリングの重心移動距離，楕円 体近似長径, フェレ径とダルシ一流速の関係

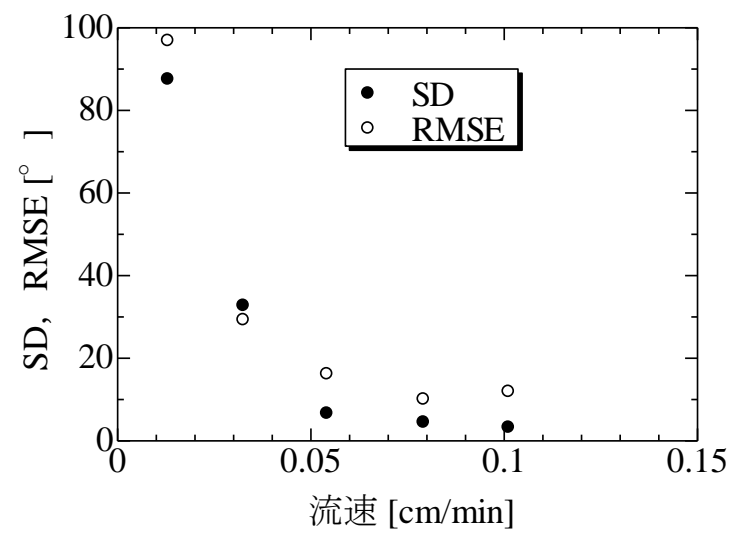

図-12 60分計測時における流向の標準偏差 (SD) および二乗 平均誤差 (RMSE)

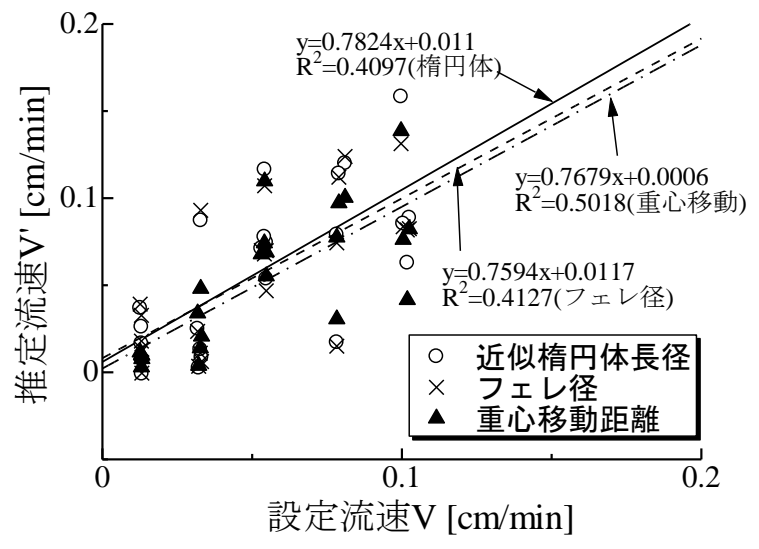

図-13 60分計測時における重心移動距離，楕円体近似長径， フェレ径を用いたダルシ一流速の推定結果

\section{（3）現地実験結果}

現地実験結果を表-3, 実験後回収したディスクを図-14に 示す. 熱量式流速計, ペーパーディスク型地下水流向流速 計ともに0.01-0.03 cm/minの流速を示し, 極めて低い流速を 示した.PDVで測定された流速は熱量式流速計に比べて やや高い傾向にあった。しかしながら両者の差は0.02 cm/min以内であった. 流向については大きく異なる場合も あったがテーリングが一定方向に長く伸びている場合には 熱量式と極めて良く一致した.

図-15にPDVで測定した流速と流向差を示した. PDVで 計測された流速が増大寸るにつれて流向差が小さくなる傾 向にあった.これは60分測定時の流向の標準偏差が 0.03 $\mathrm{cm} / \mathrm{min}$ 以下で増大したこと(図-12) と整合している. PDVの 60分間計測時には $0.033 \mathrm{~cm} / \mathrm{min}$ 以上の流速においては流 向が熱量式流速計と一致することを示している. なお, これ はテーリング重心移動の実長で $0.35 \mathrm{~cm}$ に相当する.

流向流速の測定の障害になる要素として, 副テーリング の問題がある. 副テーリングとは主テーリングから横方向に 張り出したテーリングのことである. に副テーリングが出現し たディスクの例を図-16に示す.ドットから上に向から主テー リングとは別に右上方向に伸びる副テーリングが確認できる.

表-3 各流速計による実験結果 (PDV:ペーパーディスク型地下 水流向流速計, 2015.7.18-7. 19, サロベツ湿原)

\begin{tabular}{ccccccc}
\hline \multirow{2}{*}{ No. } & \multicolumn{3}{c}{ 流向 $\left(^{\circ}\right)$} & \multicolumn{3}{c}{ 流速 $(\mathrm{cm} / \mathrm{min})$} \\
\cline { 2 - 7 } & 熱量式 & PDV & 差 & 熱量式 & PDV & 流速差 \\
\hline 1 & 132 & 133 & 1 & 0.013 & 0.033 & 0.020 \\
2 & 128 & 34 & -94 & 0.021 & 0.014 & -0.007 \\
3 & 159 & 103 & -56 & 0.015 & 0.029 & 0.014 \\
4 & 162 & 163 & -1 & 0.020 & 0.034 & 0.014 \\
\hline
\end{tabular}



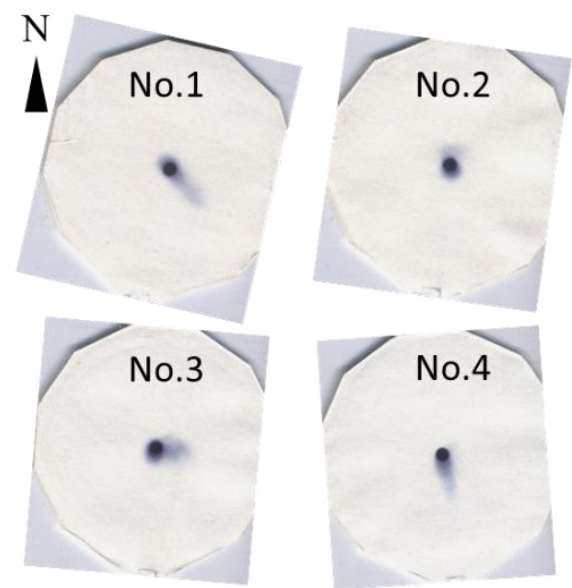

図-14 PDVの現地実験後のディスクの画像（2015. 7. 18-7. 19, サロベツ湿原環境省特別実験区，図中Nは真北の方位を 示す. ）

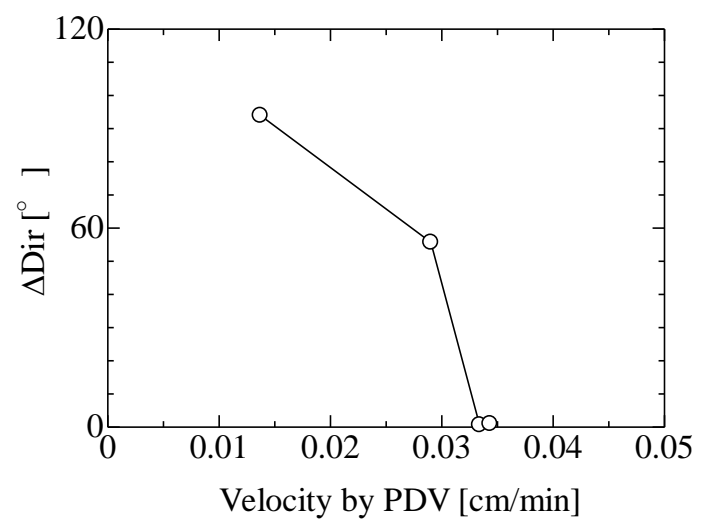

図-15 PDV と熱量式地下水流向流速計の流向の差の流速依存性

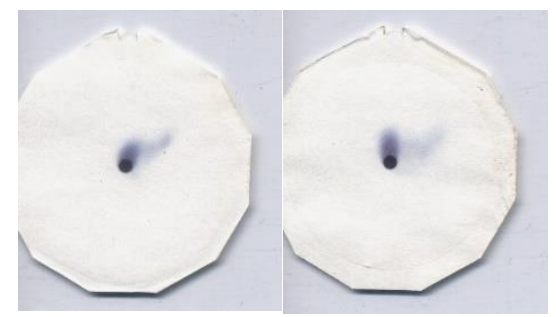

図-16 主テーリング（ドット上方向）と同時に副テーリング がドットの右上方向に出現した計測後のディスク

本計測においては図-14におけるNo.4のように単一の テーリングを持つことが理想であり，良好な解析結果を期待 できるが, 副テーリングを持つ場合には正確な流向流速を 測定することが期待できないので, このような結果が出現し た場合にはデータを破棄する必要がある.
副テーリングが出現する原因はまだ特定できていないが, 流速計センサーを挿入した後に方位を修正した場合や流 速計センサー挿入時・抜き去り時にセンサー内部に生じる 流れが影響している可能性がある.

\section{4. まとめ}

従来のペーパーディスク型地下水流向流速計を改良し， 単ドット型の計測装置を新たに開発した。計測時間5分 で0.3 $1.5 \mathrm{~cm} / \mathrm{min}$ の地下水流向・流速が計測でき, 計 測時間を 60 分とすると $0.03 \mathrm{~cm} / \mathrm{min} \sim 0.1 \mathrm{~cm} / \mathrm{min}$ の地下水 流向・流速が測定できた。サロベツ湿原における現地計 測の結果，熱量法の測定結果とほぼ齟踾の無い計測結果 になった。 十分なテーリング長が得られている場合には 熱量法と流向は完全に一致した。一定の計測時間におけ る流速の計測レンジはやや狭いが，計測時間を変化させ ることでさらに様々な流速帯に適用できる可能性がある. 水温や水質によってインクの溶出特性が変化する可能性 があるが，今後の研究課題である.

謝辞 : 本研究はJSPS科研費26303015の助成を受けた。ま た，大起理化工業株式会社との共同研究で行われたもの である. 現地実験においては環境省北海道地方環境事務 所 稚内自然保護官事務所, 北海学園大学社会環境工学 科のご協力を得た.ここに記して感謝申し上げる.

\section{参考文献}

1）小林董, 近久博志, 松本和伸, 熊谷幸樹:CCDカメラを利用した 単孔法による三次元流向流速測定に関する基礎的研究, 地 下水学会誌 vol. 45, No1, 41-48, 2003.

2）経澤正和 : 地下水の流向流速測定「熱量法」による「単孔 式」地下水流向流速計GFD3による測定，環境浄化技術, vol. 3, No. 9, 36-39, 2004.

3）齋藤宏則, 大江俊昭, 新屋敷直木, 八木原晋, 海野裕哉, 戸井田克，田中真弓，佐藤光吉，鈴木健彦，永井敏，西垣 誠 : 超音波反射エコーを用いた地下水 3 次元流向・流速測 定のための安定浮遊固体トレーサーの開発, 原子力バック エンド研究会, 13(1)，23-30，2006.

4）野田敏雄:ペーパーディスク型地下水流向流速計の開発，環 境工学研究論文集Vol. 47, 685-690, 2010.

5）小野文也, 山本浩一, 対馬幸太朗, 大石正行, 神野有生, 関根雅彦: ペーパーディスク型地下水流向流速計を用いた 海岸砂州地下水の挙動の観測. 土木学会論文集 G（環 境), 70(7), III_355-III_363, 2014.

(2015. 9. 30受付) 